\title{
Suspected Relationship between Pure Sodium and Bone Marrow Failures
}

\author{
Alok Thakur* \\ Centre for Holistic Health, Dehradun, India \\ *Corresponding Author: Alok Thakur, Centre for Holistic Health, Dehradun, India.
}

Received: July 06, 2020

Published: September 18, 2020

(C) All rights are reserved by Alok Thakur.

\begin{abstract}
Despite better healthcare infrastructure, food quality and environment incidence of haematological cancer in developed countries like Canada and the United States is more prevalent than developing countries like India. Pure sodium table salt appears to be one of the major causes of bone marrow failures leading to haematological cancer. Natural salt contains a large number of trace elements most of which have been identified as essential for the body by FDA that help in maintaining electrolyte balances and DNA health. The study has been substantiated through observations of haematological cancer among urban and rural Indian populations.
\end{abstract}

Keywords: Bone Marrow Failure; Haematological Cancer; Himalayan Rock Salt; Table Salt; Trace Elements

\section{Introduction and Methodology}

Prevalence statistics on acquired and inherited bone marrow failures in developed countries like Canada and the USA is appalling. Haematological cancer is the 4 th most frequent cancer in Canada and every 25 minutes one case is detected and every 75 minutes one death is reported. In 2014, 110,000 cases were estimated with addition of 19,130 new cases of haematological cancer $[1,2]$. Prevalence of adolescent cancers in the USA and elsewhere is linked with obesity $[3,4]$. Incidentally, sodium is strongly related with obesity as well [5]. These are the places where 100 percent pure sodium table salt is consumed through the domestic and food processing industry. Of late, India also started experiencing incidence of paediatric bone marrow failure (BMF) over the entire urban geographical area extending to nearby urban villages. Haematological cancer in India ranks 9th among all the cancers [6] compared to Canada so far. It is worthwhile to mention that India undertook salt iodization programme in 1950 (circa) to contain goitre endemic in iodine deficient areas of central India and made mandatory consumption of iodised salt through State legislature in 1998 across the country irrespective of iodine deficiency [7]. Incidence of haematological cancer before the early 1970s was almost unknown in India. These observations suggest a close relationship of BMF with consumption of pure sodium table salt. With growing consumption of iodised sodium salt incidence of haematological cancer and many other types of cancers increased.

\section{Observations}

A brief comparative chart on socio-economic lifestyle for Canada and India is presented at table 1 for assessment of reasons for incidence of haematological cancer.

\section{Interpretation of observations}

Analysing above factors impacting lifestyles of respective populations, it is surprising that despite a better lifestyle and strict state controls over pollution, adulteration and misbranding in developed countries, incidence of BMF is astronomically high in Canada as compared to India as on date. In India, BMF disorders are almost in the preliminary stage or we can say on the first step of the prevalence ladder and being reported from major 4-5 metropolitan cities like Mumbai, Delhi, Kolkata, Chennai, and Bangalore. Steady increase in bone marrow transplants throws some light on the incidence trend. Between 1986 and 2007 an average 45 cases of bone marrow transplants were carried out each year at CMC Vellore [8] medical facility near Chennai, this number rose to 200 each year by 2015. According to the GLOBOCAN 2012 report of World Health Organization (WHO) International Agency for Research in Cancer, India has the third largest number of haematological cancers after the USA and China with 32,000 cases in 2012 and 26,000 non-Hodgkin's lymphoma and 16,000 deaths [8]. According to the National Cancer Registry Programme of the Indian Council of Medical Research (ICMR) more than 1300 die every day due to various 


\begin{tabular}{|c|c|c|}
\hline$\#$ & Canada & India \\
\hline 1. & $\begin{array}{c}\text { Developed country almost } \\
\text { for a } \\
\text { Century. }\end{array}$ & $\begin{array}{c}\text { Still a developing country in } \\
21^{\text {st }} \text { century. }\end{array}$ \\
\hline 2. & $\begin{array}{c}\text { Per capita income in 2017: } \\
\$ 45,750\end{array}$ & $\begin{array}{c}\text { Per capita income in 2017: } \\
\$ 7060\end{array}$ \\
\hline 3. & $\begin{array}{c}\text { Exposure to pesticides, insec- } \\
\text { ticides, and other agriculture } \\
\text { aides like fertilizers, auxins } \\
\text { within permissible limits. }\end{array}$ & $\begin{array}{c}\text { No effective control; thus } \\
\text { products are highly laced with } \\
\text { various agro-chemicals. Some } \\
\text { of these are carcinogenic. }\end{array}$ \\
\hline
\end{tabular}

4. Serious food adulteration with Population is exposed to high toxic materials like chemical levels of adulteration and toxic dyes and non-edible substanc- adulteration in food. es is unheard.

5. Highly nutritional diet. $\quad \begin{gathered}\text { Majority of rural and semi- } \\ \text { urban population is deprived } \\ \text { of nutritional diet due to } \\ \text { economic factors. }\end{gathered}$

6. Hygiene levels are very high. Hygiene levels are very low especially in the countryside and poor segments of the society.

\begin{tabular}{c|c|c} 
7. & $\begin{array}{c}\text { Availability of narcotics } \\
\text { restricted. }\end{array}$ & $\begin{array}{c}\text { Availability of narcotics is } \\
\text { easier. }\end{array}$
\end{tabular}

8. State-of-art medical facilities Very poor coverage even for available to all.

9. Consumption of natural sea Consumption of natural sea and rock salt is almost negli- and rock salt despite state polgible and rare.

10. High level of incidence of haematological cancer. Number increased by $25 \%$ from 2014 to 2016 . icy of iodized table salt is still high among socially weaker populace in the countryside.

Only a handful of cases were reported in the 1970s. Rapidly increasing at paediatric stage and new adults.

Table 1: Comparison of socio-economic status and BMF incidence.

types of cancers in India [6]. During 2012-14, the mortality rate due to all cancers increased by approximates 6\%. In 2012, there were 478,180 deaths out of $1,934,314$ cases reported while in 2018, mortality was 784,821 out of estimated living 2.25 million with addition of 1,157,294 new cases. A mathematical insight on body metabolism dynamics at cellular levels pinpoints towards consumption of refined pure sodium salt on the prevalence of noncommunicable diseases [8]. Though in India, iodized pure sodium salt was introduced in 1962 as National Goitre Control Programme assisted by WHO and UNICEF, but it was enforced for all in 1998 through state legislature $[6,10]$. During this intervening period, the urban population adopted the refined iodized sodium salt whereas rural population could not adopt it due to financial constraints being almost 5-6 times costlier than sea salt and this is clearly visible in the incidence of haematological cancer in urban and rural areas.

\section{Discussion}

Extensive work on BMF has been documented in the annals of medical science that includes damage to hematopoietic stem cells and their microenvironment, maturation defects due to vitamin B-12 or folate deficiency, and differentiation defects like myelodysplasia. Electrolyte composition governing cell microenvironment is one of the vital parameters for correct metabolism at cellular level and solely depends upon dietary profile. Salt is most consumed dietary item on a regular daily basis, so it is likely to have a dominant effect on dynamics of different cells.

India alone consumes $\$ 0.35$ billion worth of branded sodium per year amounting to about 3.8 million tons and growing 7-8 percent annually [10]. These branded salts contain more than 99.999 percent of sodium salt fortified with $>15 \mathrm{ppm}$ iodine along with anti-lumping agents those again contain sodium. Iodised table salt doesn't contain any other micro mineral or trace elements found in the unprocessed rock or sea salts. Natural salts contain micro minerals and 86 trace elements including 12 radioactive elements (MMTE) in case of Himalayan rock salt, table 2, and account for almost $14 \%$ by weight of the natural salt [11].

Manufacturing process of refined free flowing table salt completely removes MMTE components from the natural salt, and is substituted by sodium and sodium based anti-lumping agents. Daily intake of sodium salt bring in major changes in electrolyte composition leading to impairment of various fundamental cell processes such as Na-K pump, calcium pump, and a whole lot of thermodynamic and chemical equilibrium. Once the body's smart adaptive system recognizes electrolytic changes on an everyday basis, it tries to normalize the changed situation by internal adjustments that make the body metabolism dynamics topsy-turvy with unpredictable outcomes. So far the USA Food and Drug Administration could understand and identified 60 elements of the natural salt as essential nutrients [12]. In June 2016, the US National Research Council labelled 29 of these 60 micro and trace elements as "possibly" or "probably" essential and beneficial to human health. These include bromine, boron, chromium, calcium, copper, fluoride, iodine, iron, manganese, magnesium, molybdenum, potassium, phosphorus, selenium, silver, sulphur, and zinc. The 14 percent fraction of natural salt consisting of MMTE that contains these 29 identified essential elements is large enough to ignore and neglect. Supplementation of these essential elements is no substitute for natural occurrence in the unprocessed natural salt. Rest of the trace ele- 


\begin{tabular}{|c|c|c|c|c|c|c|c|}
\hline S. No. & Element & Atomic No. & Concentration & S. No. & Element & Atomic No. & Concentration \\
\hline 1. & Hydrogen & 1 & $0.3 \mathrm{~g} / \mathrm{kg}$ & 45. & Indium & 49 & $<0.001 \mathrm{ppm}$ \\
\hline 2. & Lithium & 3 & $0.4 \mathrm{~g} / \mathrm{kg}$ & 46. & Tin & 50 & $<0.01 \mathrm{ppm}$ \\
\hline 3. & Beryllium & 4 & $<0.01 \mathrm{ppm}$ & 47. & Antimony & 51 & $<0.01 \mathrm{ppm}$ \\
\hline 4. & Boron & 5 & $<0.001 \mathrm{ppm}$ & 48. & Tellurium & 52 & $<0.001 \mathrm{ppm}$ \\
\hline 5. & Carbon & 6 & $<0.001 \mathrm{ppm}$ & 49. & Iodine & 53 & $0.01 \mathrm{~g} / \mathrm{kg}$ \\
\hline 6. & Nitrogen & 7 & $<0.024 \mathrm{ppm}$ & 50. & Cesium & 55 & $<0.001 \mathrm{ppm}$ \\
\hline 7. & Oxygen & 8 & $1.2 \mathrm{~g} / \mathrm{kg}$ & 51. & Barium & 56 & $1.96 \mathrm{ppm}$ \\
\hline 8. & Fluoride & 9 & $<0.1 \mathrm{~g} / \mathrm{kg}$ & 52. & Lanthanum & 57 & $<0.001 \mathrm{ppm}$ \\
\hline 9. & Sodium & 11 & $382.61 \mathrm{~g} / \mathrm{kg}$ & 53. & Cerium & 58 & $<0.001 \mathrm{ppm}$ \\
\hline 10. & Magnesium & 12 & $0.16 \mathrm{~g} / \mathrm{kg}$ & 54. & Praseodymium & 59 & $<0.001 \mathrm{ppm}$ \\
\hline 11. & Aluminium & 13 & $0.661 \mathrm{ppm}$ & 55. & Neodymium & 60 & $<0.001 \mathrm{ppm}$ \\
\hline 12. & Silicon & 14 & $<0.1 \mathrm{~g} / \mathrm{kg}$ & 56. & Promethium* & 61 & Unstable \\
\hline 13. & Phosphorus & 15 & $<0.1 \mathrm{ppm}$ & 57. & Samarium & 62 & $<0.001 \mathrm{ppm}$ \\
\hline 14. & Sulphur & 16 & $1.24 \mathrm{~g} / \mathrm{kg}$ & 58. & Europium & 63 & $<3.0 \mathrm{ppm}$ \\
\hline 15. & Chloride & 17 & $590.93 \mathrm{~g} / \mathrm{kg}$ & 59. & Gadolinium & 64 & $<0.001 \mathrm{ppm}$ \\
\hline 16. & Potassium & 19 & $3.5 \mathrm{~g} / \mathrm{kg}$ & 60. & Terbium & 65 & $<0.001 \mathrm{ppm}$ \\
\hline 17. & Calcium & 20 & $4.05 \mathrm{~g} / \mathrm{kg}$ & 61. & Dysprosium & 66 & $<0.4 \mathrm{ppm}$ \\
\hline 18. & Scandium & 21 & $<0.0001 \mathrm{ppm}$ & 62. & Holmium & 67 & $<0.001 \mathrm{ppm}$ \\
\hline 19. & Titanium & 22 & $<0.001 \mathrm{ppm}$ & 63. & Erbium & 68 & $<0.001 \mathrm{ppm}$ \\
\hline 20. & Vanadium & 23 & $0.06 \mathrm{ppm}$ & 64. & Thulium & 69 & $<0.001 \mathrm{ppm}$ \\
\hline 21. & Chromium & 24 & $0.05 \mathrm{ppm}$ & 65. & Ytterbium & 70 & $<0.001 \mathrm{ppm}$ \\
\hline 22. & Manganese & 25 & $0.27 \mathrm{ppm}$ & 66. & Lutetium & 71 & $<0.001 \mathrm{ppm}$ \\
\hline 23. & Iron & 26 & $38.9 \mathrm{ppm}$ & 67. & Hafnium & 72 & $<0.001 \mathrm{ppm}$ \\
\hline 24. & Cobalt & 27 & $0,6 \mathrm{ppm}$ & 68. & Tantalum & 73 & $1.1 \mathrm{ppm}$ \\
\hline 25. & Nickel & 28 & $0.13 \mathrm{ppm}$ & 69. & Wolfram & 74 & $<0.001 \mathrm{ppm}$ \\
\hline 26. & Copper & 29 & $0.56 \mathrm{ppm}$ & 70. & Rhenium & 75 & $<2.5 \mathrm{ppm}$ \\
\hline 27. & Zinc & 30 & $2.38 \mathrm{ppm}$ & 71. & Osmium & 76 & $<0.001 \mathrm{ppm}$ \\
\hline 28. & Gallium & 31 & $<0.001 \mathrm{ppm}$ & 72. & Iridium & 77 & $<2.0 \mathrm{ppm}$ \\
\hline 29. & Germanium & 32 & $<0.001 \mathrm{ppm}$ & 73. & Platinum & 78 & $0.47 \mathrm{ppm}$ \\
\hline 30. & Arsenic & 33 & $<0.01 \mathrm{ppm}$ & 74. & Gold & 79 & $<1.0 \mathrm{ppm}$ \\
\hline 31. & Selenium & 34 & $0.05 \mathrm{ppm}$ & 75. & Mercury & 80 & $<0.03 \mathrm{ppm}$ \\
\hline 32. & Bromine & 35 & $2.1 \mathrm{ppm}$ & 76. & Thallium & 81 & $0.06 \mathrm{ppm}$ \\
\hline 33. & Rubidium & 37 & $0.04 \mathrm{ppm}$ & 77. & Lead & 82 & $0.01 \mathrm{ppm}$ \\
\hline 34. & Strontium & 38 & $0.014 \mathrm{~g} / \mathrm{kg}$ & 78. & Bismuth & 83 & $<0.01 \mathrm{ppm}$ \\
\hline 35. & Yttrium & 39 & $<0.001 \mathrm{ppm}$ & 79. & Polonium ${ }^{*}$ & 84 & $<0.001 \mathrm{ppm}$ \\
\hline 36. & Zirconium & 40 & $<0.001 \mathrm{ppm}$ & 80. & Astatine $^{*}$ & 85 & $<0.001 \mathrm{ppm}$ \\
\hline 37. & Niobium & 41 & $<0.001 \mathrm{ppm}$ & 81. & Francium ${ }^{*}$ & 87 & $<1.0 \mathrm{ppm}$ \\
\hline 38. & Molybdenum & 42 & $0.01 \mathrm{ppm}$ & 82. & Radium ${ }^{*}$ & 88 & $<0.001 \mathrm{ppm}$ \\
\hline 39. & Technetium ${ }^{*}$ & 43 & Unstable & 83. & Actinium ${ }^{*}$ & 89 & $<0.001 \mathrm{ppm}$ \\
\hline 40. & Ruthenium & 44 & $<0.001 \mathrm{ppm}$ & 84. & Thorium ${ }^{*}$ & 90 & $<0.001 \mathrm{ppm}$ \\
\hline 41. & Rhodium & 45 & $<0.001 \mathrm{ppm}$ & 85. & Protactinium $^{*}$ & 91 & $<0.001 \mathrm{ppm}$ \\
\hline 42. & Palladium & 46 & $<0.001 \mathrm{ppm}$ & 86. & Uranium $^{*}$ & 92 & $<0.001 \mathrm{ppm}$ \\
\hline 43. & Silver & 47 & $0.031 \mathrm{ppm}$ & 87. & Neptunium ${ }^{*}$ & 93 & $<0.001 \mathrm{ppm}$ \\
\hline 44. & Cadmium & 48 & $<0.01 \mathrm{ppm}$ & 88. & Plutonium $^{*}$ & 94 & $<0.001 \mathrm{ppm}$ \\
\hline
\end{tabular}

Table 2: Spectral analysis of Himalayan rock salt.

* Radioactive elements. 
ments must have also played a much bigger role in human body evolution over millions of years but their contributions have not been understood completely.

\section{Conclusion}

It is observed that prevalence of non-communicable diseases including haematological cancer in India spreads from metropolitan cities to smaller cities, villages adjacent to cities $[9,10]$. Very remote rural population which is economically poor still depend upon natural sea salt, being cheaper in cost compared to branded iodized salt and as a blessing in disguise they are almost untouched by the burden of non-communicable diseases including cancer or haematological cancer. With passing times, consumption of pure iodized sodium salt is increasing almost at a rate of $6-7$ percent that almost matches growth in incidence of haematological cancer. It is, therefore, logically interpreted and inferred that sodium table salt without MMTE plays a key role in BMF on account of impairment of microenvironment of hematopoietic cells. Moreover, it is also felt that initially BMF is acquired on account of excess sodium consumption from refined manufactured table salt leading to impairment of DNA due to deprivation of magnesium and other MMTE, and then inheritance starts playing a bigger role in prevalence of haematological cancer. It is interesting to mention that almost all instances of haematological cancer reported are found to be from the population consuming synthetic iodized sodium table salt. It is also observed in this limited study that Indian adults in the present age group 30-50 years who have switched from natural salt to synthetic sodium salt remained unaffected compared to children who start their life with synthetic sodium salt and falling prey to bone marrow failure perhaps due to more susceptibility of BMF at the paediatric stage on account of exposure to imbalanced exposure to sodium right from the fetus state.

\section{Acknowledgements}

Author is grateful to voluntary participation of families in the study.

\section{Conflict of Interest}

None.

\section{Funding}

None.

\section{Bibliography}

1. Leukemia and Lymphoma Society of Canada. "Facts and Statistics".

2. JM Steele., et al. "Disease progression in recently diagnosed patients with inherited marrow failure syndromes: A Canadian inherited marrow failure registry (CIMFR) report". Pediatric Blood Cancer 47(2006): 918-925.
3. S Hyuna., et al. "Emerging cancer trends among young adults in the USA: analysis of a population-based cancer registry". The Lancet Public Health (2019).

4. A Furer., et al. "Adolescent obesity and midlife cancer risk: a population based cohort study of $2 \cdot 3$ million adolescents in Israel". Lancet Diabetes Endocrinology 8 (2020): 216-225.

5. University of Helsinki. "Salt Intake Is Strongly Associated with Obesity Science Daily".

6. Indian Council of Medical Research, Government of India. National Cancer Registry Programme.

7. Salt Commissioner. Salt iodization Programme in India

8. It isn't just the disease that kills most blood cancer patients in India - it's the wait.

9. A Thakur. "Decoding increasing prevalence of noncommunicable diseases". International Journal of Noncommunicable Diseases 3 (2018): 139-144.

10. A Thakur. "Suspected root cause of non-communicable diseases epidemic". International Journal of Life Sciences Research 5 (2017): 116-120.

11. Minerals in Himalayan Pink Salt: Spectral Analysis.

12. US FDA Guidance for Industry. A food Labeling Guide 14, Appendix F.

\section{Assets from publication with us}

- Prompt Acknowledgement after receiving the article

- Thorough Double blinded peer review

- Rapid Publication

- Issue of Publication Certificate

- High visibility of your Published work Website: www.actascientific.com/ Submit Article: www.actascientific.com/submission.php Email us: editor@actascientific.com Contact us: +919182824667 